\title{
Production of antilisterial bacteriocins by staphylococci isolated from bovine milk ${ }^{1}$
}

\author{
M. A. V. P. Brito, ${ }^{\star}$ G. A. Somkuti, $t^{2}$ and J. A. Renye Jr. $\dagger$ \\ *EMBRAPA Dairy Cattle Research Center, Juiz de for a 36038, Brazil \\ †Eastern Regional Research Center, United States Department of Agriculture, Wyndmoor, PA 19038
}

\section{ABSTRACT}

A collection of 111 staphylococcal isolates recovered from healthy cows in 41 dairy herds in Brazil was surveyed for the production of bacteriocins. The group included 94 coagulase-positive and 17 coagulase-negative strains of staphylococci. All cultures were grown in tryptic soy broth for $18 \mathrm{~h}$ at $37^{\circ} \mathrm{C}$, and cell-free supernatants were tested for antimicrobial activity against several target organisms by using the agar diffusion method. Filtrates of 57 staphylococci showed strong activity against Listeria monocytogenes Scott A, and 52 isolates also inhibited the growth of Stapylococcus aureus Newbould 305, a major causative agent of bovine mastitis in the United States. The plasmid profiles of staphylococci invariably included an 8-kb plasmid. Staphylococcal isolates were tested for the production of aureocins A70 and A53, 2 bacteriocins of coagulasepositive staphylococci known to be associated with 8 -kb and 10.2-kb plasmids, respectively. The presence of the A70 or A53 bacteriocin gene was checked by PCR techniques using primers based on nucleotide sequences flanking the structural gene of each bacteriocin. Agarose gel analysis of amplified PCR products of plasmid templates from all 58 isolates showed only a 525-bp fragment corresponding to the structural gene of the bacteriocin aureocin A70. The results indicated that the apparently widespread association of A70producing staphylococci with healthy cows in Brazil may be beneficial in controlling undesirable bacteria in dairy herds.

Key words: staphylococci from milk, antilisterial activity, bacteriocin

\footnotetext{
Received September 22, 2010.

Accepted November 27, 2010.

${ }^{1}$ Mention of trade names or commercial products in this publication is solely for the purpose of providing specific information and does not imply recommendation of endorsement by the US Department of Agriculture.

${ }^{2}$ Corresponding author: george.somkuti@ars.usda.gov
}

\section{INTRODUCTION}

Bacterial cells produce several types of substances that have inhibitory activity against other bacteria. These substances constitute a diverse class of molecules and have been identified, for example, as hydrogen peroxide, lactic acid, exotoxins, lytic enzymes, classical antibiotics, and bacteriocins (Jack et al., 1995). Bacteriocins are ribosomally synthesized antimicrobial peptides that are produced by many different bacterial species. The inhibitory activity is generally directed against the same or closely related species (Jack et al., 1995).

Bacteriocins have been found over the whole range of gram-negative and gram-positive species and have been isolated from a variety of habitats. Several bacteriocins have been extensively studied because there is growing interest in their potential application as food preservatives (Jack et al., 1995; Deegan et al., 2006). Nisin, which is produced by several strains of lactococci, is approved for food uses in more than 40 countries and has been used as a food preservative for over $50 \mathrm{yr}$ (Chen and Hoover, 2003). Other bacteriocins from lactic acid bacteria such as pediocin and lacticin may also have applications as biopreservatives (O'Sullivan et al., 2002).

The growing interest in bacteriocins is also guided by their potential in therapeutic applications. The rise and spread of multidrug-resistant bacterial pathogens has motivated research for alternative antimicrobials to treat infectious diseases. Natural antimicrobial peptides such as bacteriocins may be valuable as supplemental agents in overcoming the growing problem of resistance to conventional antibiotics (Papagianni, 2003).

The antimicrobial spectrum of staphylococcal bacteriocins varies and may include species of the genera Staphylococcus, Streptococcus, Bacillus, Clostridium, Corynebacterium, and Listeria. Staphylococcins were described in Staph. aureus isolated from human skin lesions belonging to phage group II type 71 (Barrow, 1963; Dajani and Wannamaker, 1969). Examples of these bacteriocins are produced by Staph. aureus strains C55 and UT007 (Warren et al., 1975; Rogolsky and Wiley, 
1977; Crupper et al., 1997). It was subsequently established that these 2 staphylococcins are similar and that the bacteriocins structural genes were closely associated with the exfoliative toxin $\mathrm{B}$ determinant, which is located on the same plasmid. The staphylococcins belong to the group of 2-component lantibiotics (Navaratna et al., 1998, 1999). Additional bacteriocins produced by strains of Staph. aureus include staphylococcins 414 (Gagliano and Hinsdill, 1970), 462, and Bac1829 (Crupper and Iandolo, 1996), and the aureocins A53 and A70 (Giambiagi-Marval et al., 1990). Aureocins A53 and A70 are plasmid-mediated nonlantibiotic bacteriocins that were described in Staph. aureus isolated from pasteurized milk. The antimicrobial activity of aureocin A70 requires the presence of 4 unmodified peptides (Netz et al., 2001). Aureocin A53 is characterized by a rigid structure in aqueous solution that is markedly resistant to protease activity (Netz et al., 2002).

Several bacteriocins are produced by strains of Staphylococcus epidermidis. They include epidermin and its variant Val-1 Leu-6 epidermin (Sahl and Bierbaum, 1998), Pep5 (Sahl and Brandis, 1981; Sahl and Bierbaum, 1998), epicidin 280 (Heidrich et al., 1998), epilancin K (Van de Kamp et al., 1995), and the closely related epilancin 15X (Ekkelenkamp et al., 2005). Gallidermin (Leu-6 epidermin) produced by Staphylococcus gallinarum (Schnell et al., 1989) is also considered a natural variant of epidermin (Sahl and Bierbaum, 1998). All of these bacteriocins share a common feature of being elongated cationic type A lantibiotics and, with a few exceptions, their genetic determinants are carried on plasmids (Schnell et al., 1989; Van de Kamp et al., 1995; Ekkelenkamp et al., 2005). Two bacteriocins have been reported in Staphylococcus warneri, warnericin and nukacin ISK-1. The second is produced by Staph. warneri ISK-1 and has been characterized as a type A lantibiotic structurally similar to lacticin- 481 (Sashihara et al., 2000; Minamikawa et al., 2005). Other staphylococci species that have been reported as bacteriocin producers include Staphylococcus simulans, Staphylococcus saprophyticus, Staphylococcus hominis, and Staphylococcus arlettae (Nascimento et al., 2005a).

In the present study, a collection of staphylococci recovered from the milk of healthy cows from several farms in Brazil was screened for bacteriocin production. The research focused on the activity spectrum of putative bacteriocins of staphylococcal isolates and applying PCR techniques to determine whether the bacteriocins detected were novel or similar to others described previously in the literature. Molecular techniques were also used to reduce the size of a bacteriocin plasmid and to evaluate its transferability to Staphylococcus carnosus, a food-grade species in the genus Staphylococcus that is used as a starter culture in fermented sausages.

\section{MATERIALS AND METHODS}

\section{Source of Staphylococci and Culture Conditions}

Staphylococci isolates $(\mathrm{n}=111)$ were obtained from freshly drawn bovine milk samples from 41 dairy herds located in the southeast and northeast regions of Brazil. Milk samples were collected from individual cows just before milking and staphylococci were isolated on blood agar plates. They were identified as coagulasepositive (94) and coagulase-negative (17) according to colony and cellular characteristics, catalase production, and tube-coagulase test. The identity of 3 coagulasepositive staphylococci (numbers 48, 76, and 80) was further evaluated by the agglutination test for protein A and clumping factor (BactiStaph, Remel, Lenexa, $\mathrm{KS})$.

In the genetic transformation experiments, host strains included Staph. aureus SA113 (ATCC 35556) and a commercial strain of Staph. carnosus (CS 299 Bactoferm, Chr. Hansen Laboratories, Milwaukee, WI). All staphylococcal strains were cultured in tryptic soy broth (TSB, Becton, Dickinson and Co., Franklin Lakes, NJ) and stored under refrigeration conditions with monthly transfers. Long-term storage of cultures was at $-80^{\circ} \mathrm{C}$ in TSB containing $20 \%$ ( vol/vol) sterile glycerol.

\section{Screening for Bacteriocin Production}

Bacteriocin activity was evaluated by the agar-well diffusion method (Tagg and McGiven, 1971). The producer strains were grown overnight in TSB, and $50 \mu \mathrm{L}$ of cell-free culture supernatants were transferred into wells cut in agar plates that were previously inoculated with selected indicator bacterial strains. After inoculation, the plates were stored for up to $16 \mathrm{~h}$ at $4^{\circ} \mathrm{C}$, followed by incubation at $32^{\circ} \mathrm{C}$ for Listeria species or $37^{\circ} \mathrm{C}$ for Staphylococcus species. The presence of an inhibition zone indicated the production of antibacterial substances. The indicator strains included Listeria monocytogenes Scott A (LMS, ATCC 49594), Listeria ivanovii (LIV, ATCC 19119) and Staph. aureus Newbould 305 (SA305, ATCC 29740), a bovine mastitis agent frequently isolated in the United States (Guidry et al., 1998).

Bacteriocin activity was measured by the spot-onthe-lawn method (Henderson et al., 1992) following a 2 -fold dilution with distilled water of cell-free supernatants of 18-h broth cultures. Five-microliter aliquots of samples were spotted on lawns seeded with LMS. The titer, in arbitrary units (AU) per milliliter, was defined as the reciprocal of the highest dilution still producing a visible inhibition zone. 
Thermal stability of the putative bacteriocins in selected staphylococcal isolates was tested by heating cell-free supernatants for $10 \mathrm{~min}$ at 80 and $100^{\circ} \mathrm{C}$ and for $15 \mathrm{~min}$ at $121^{\circ} \mathrm{C}$ in the autoclave. Nonheated control samples were kept at $4^{\circ} \mathrm{C}$. After heating, the samples were cooled, serially diluted, and tested for activity against LMS by the spot-on-the-lawn agar diffusion method.

\section{Plasmid Isolation and Molecular Genetic Techniques}

Large-scale isolation of plasmids was carried out according to a previously published protocol (Somkuti and Steinberg, 1988) and further purified by $\mathrm{CsCl} /$ ethidium bromide ultracentrifugation (Stougaard and Molin, 1983). Small-scale plasmid isolation was done by the rapid mini-prep method of O'Sullivan and Klaenhammer (1993). Staphylococcal cells were lysed by adding a $2 \mathrm{mg} / \mathrm{mL}$ lysostaphin (Sigma-Aldrich, St. Louis, $\mathrm{MO})$ solution in $20 \mathrm{mM}$ Tris $(\mathrm{pH}$ 8.2). Plasmid DNA was analyzed by agarose gel electrophoresis (AGE) in Tris-borate-EDTA buffer (0.089 $M$ Tris base, $0.089 M$ boric acid, $0.002 M$ Na-EDTA, $\mathrm{pH} 8$ ). The digestion of purified plasmids with HincII, EcoRI, EcoRV, and PstI restriction endonucleases was carried out as recommended by the manufacturer (New England Biolabs, Beverly, MA).

\section{PCR Amplifications and 16S rDNA Analysis}

Amplifications of known aureocin genes with specific oligonucleotides primers were made using as templates either total DNA recovered by the Prepman Ultra DNA isolation reagent (Applied Biosystems, Foster City, $\mathrm{CA}$ ) or the isolated plasmids. The primers used were as follows: 5'-GATTAAACCTTATAATAGA-3' (forward) and $5^{\prime}$-CTAATAATAAAATATTAACAA-3' (reverse) for the aureocin A70 operon (aurABCD); 5'-GAAGTTATGAAAACTATA-3' (forward) and 5'-CATAAAACAAAGAACCAAAGT-3' (reverse) for aureocin A53 $(a u c A)$; and 5'-GAGTGGAGAAACAGTAGT-3' (forward) and 5'- CTATTCTTCCCAATTCAT-3' (reverse) for the replicon region of $\mathrm{pRJ} 6$, the original plasmid of aureocin A70-producing strain (Giambiagi-Marval et al., 1990). The primers for aureocins A70 and A53 were based on Nascimento et al. (2005a), and primers for pRJ6 replicon were designed according to the published partial sequence of the plasmid (Netz et al., 2001). The PCR reactions were carried out in a $50-\mu \mathrm{L}$ volume containing $45 \mu \mathrm{L}$ of Platinum PCR Supermix (Applied Biosystems), $2 \mu \mathrm{L}$ of each primer, and $1 \mu \mathrm{L}$ of DNA template. After the denaturing step of $3 \mathrm{~min}$ at $94^{\circ} \mathrm{C}$, the protocol consisted of 35 amplification cycles: $5 \mathrm{~s}$ at $94^{\circ} \mathrm{C}, 30 \mathrm{~s}$ at $45^{\circ} \mathrm{C}$, and $90 \mathrm{~s}$ at $72^{\circ} \mathrm{C}$. The PCR products were separated on $1.0 \%$ agarose gel electrophoresis and visualized under UV light after staining with ethidium bromide. An A70 aureocin-producing Staphylococcus culture (strain 4147, gift of M. C. Bastos, Federal University of Rio de Janeiro, Brazil) was used as a positive control.

Isolated genomic DNA was used as template for PCR with the eubacterial oligonucleotide primers EubA and EubB (Cottrell and Kirchman, 2000) for the amplification of $16 \mathrm{~S}$ rRNA genes. The PCR products were cleaned with the QIAquick PCR Purification Kit (Qiagen Inc., Valencia, CA) and sequenced.

Nucleic acid sequencing of PCR products was performed using an ABI Prism 3730 DNA analyzer with ABI Prism Big Dye terminator cycle sequencing reagent (Perkin-Elmer, Wellesley, MA). Sequences were analyzed using Sequencher 4.2 (Gene Codes Corp., Ann Arbor, MI) and compared with sequences available in GenBank using the National Center for Biotechnology Information BLASTN search program (http://www. ncbi.nlm.nih.gov/BLAST/).

\section{Transformation of Staph. aureus and Staph. carnosus}

Transfer of the bacteriocin plasmid to Staph. aureus SA113 and Staph. carnosus CS299 was performed by electroporation. The recipient bacteria were cultivated overnight in $5 \mathrm{~mL}$ of B2 medium (Schenk and Laddaga, 1992) incubated at $37^{\circ} \mathrm{C}$. An overnight culture was used to inoculate $25 \mathrm{~mL}$ of $\mathrm{B} 2$ medium $(1 \%, \mathrm{vol} / \mathrm{vol})$ followed by incubation as above until reaching an optical density value at $660 \mathrm{~nm}$ of 0.5 to 0.6 . The culture was chilled on ice for $15 \mathrm{~min}$ and the cells harvested by centrifugation at $10,000 \times g$ for $10 \mathrm{~min}$ at $4^{\circ} \mathrm{C}$. The cells were washed 3 times with an equal volume of sterile water, washed once with $5 \mathrm{~mL}$ of $500 \mathrm{mM}$ sucrose, $1 \mathrm{mM} \mathrm{MgSO}$, and $1 \mathrm{~m} M$ HEPES buffer (SMH, pH 7.0), suspended in 2.5 $\mathrm{mL}$ of SMH buffer, and incubated at $20^{\circ} \mathrm{C}$ for $15 \mathrm{~min}$. The cells were again centrifuged and resuspended in 1.0 $\mathrm{mL}$ of SMH buffer.

For electroporation, 20 to $25 \mu \mathrm{g}$ of plasmid DNA was added to $100 \mu \mathrm{L}$ of the cell suspension in a $0.2-\mathrm{cm}$ cuvette. Using a BioRad Gene Pulser (Bio-Rad Laboratories, Richmond, CA), a single pulse was delivered at $2.5 \mathrm{kV}, 100 \Omega$, and $25 \mu \mathrm{F}$, giving a field strength of 12.5 $\mathrm{kV} / \mathrm{cm}$. Immediately after pulsing, $900 \mu \mathrm{L}$ of SMMP (0.5 $M$ sucrose, $20 \mathrm{~m} M$ maleic acid, $20 \mathrm{~m} M \mathrm{MgCl}_{2}$, $3.5 \%$ Difco Penassay broth, $\mathrm{pH}$ 6.5) was added to the cuvette (Augustin and Gotz, 1990), the transformation mixture was transferred to a sterile tube and incubated for $2 \mathrm{~h}$ at $37^{\circ} \mathrm{C}$. After incubation, $100-\mu \mathrm{L}$ aliquots were spread on plates prepared as described below, and incubated overnight at $37^{\circ} \mathrm{C}$. Selected colonies were checked 


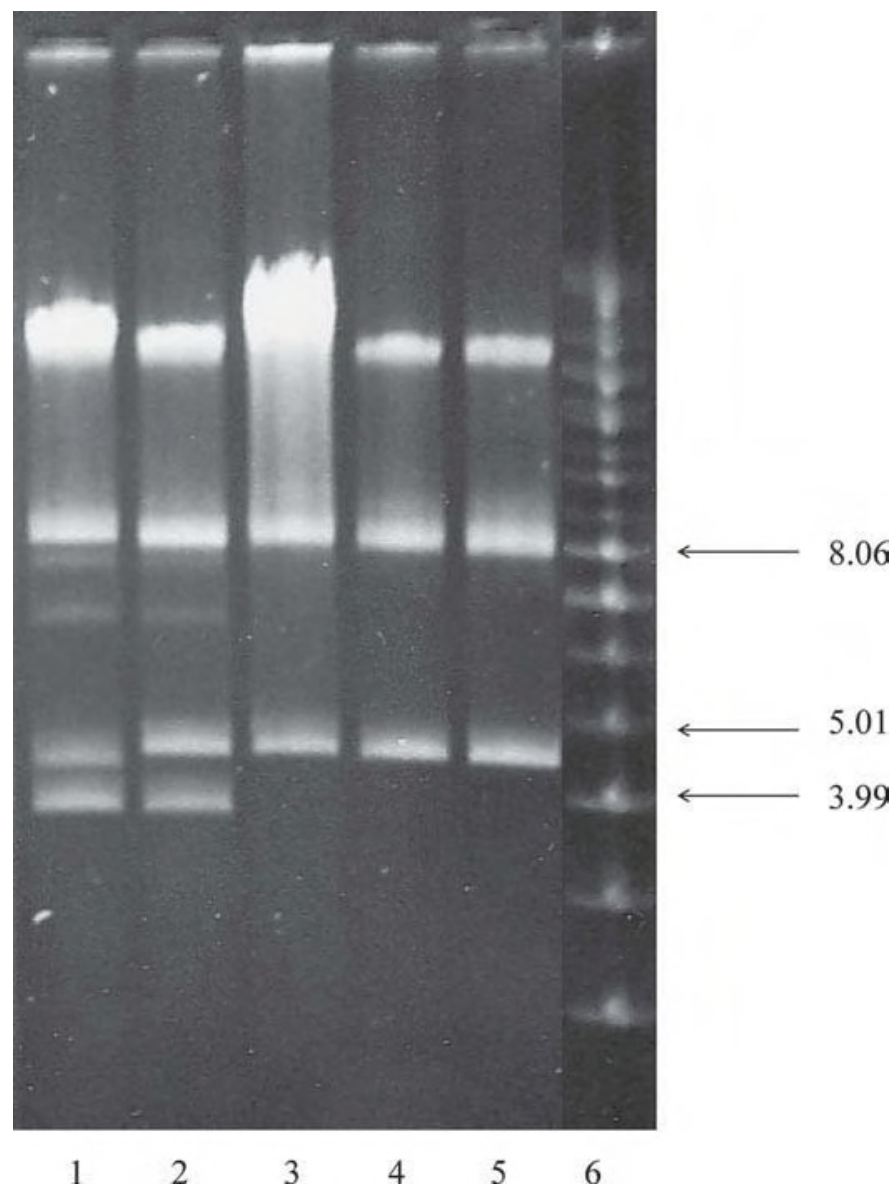

Figure 1. Plasmid profiles of staphylococcal isolates from bovine milk (lanes 1-5) and supercoiled molecular markers (lane 6).

for antibacterial activity against LMS by the agar-well diffusion method.

Because a readily detectable antibiotic marker was not available, the selection of genetic transformants was based on the assumption that uptake of the bacteriocin plasmid would also result in the acquisition of the immunity gene. Thus, the selective medium for transformed bacteria was prepared with a crude aureocin preparation, by removing the cells by centrifugation $\left(10,000 \times g, 4^{\circ} \mathrm{C}\right)$ from the overnight culture (TSB) of a producer strain, adjusting the supernatant to $\mathrm{pH} 7.0$ with $5 \mathrm{M} \mathrm{NaOH}$, adding agar at $1.5 \%$ (wt/vol), and autoclaving the medium at $121^{\circ} \mathrm{C}$ for $17 \mathrm{~min}$ before pouring plates.

\section{RESULTS AND DISCUSSION}

The results of the screening for antibacterial activity of the 111 isolates of staphylococci are summarized in Table 1. A total of $57(51.4 \%)$ isolates showed antimicrobial activity and, with the exception of 5 isolates, all strains showing activity against LMS also inhibited SA305, but only 43 isolates $(38.7 \%)$ had inhibitory activity against LIV.

Among the staphylococcal isolates, strains 48, 76, and 80 produced the largest inhibition zones against indicator bacteria (LMS, SA305, and LIV) and were selected for further studies. All 3 strains agglutinated with antiserum for protein A and clumping factor and were designated as Staph. aureus. The identity of strain 80 was further confirmed by PCR amplification of $16 \mathrm{~S}$ ribosomal DNA. Subsequent comparison of sequences with the BLAST database showed $100 \%$ identity with Staph. aureus.

The antibacterial activity of strains 48,76 , and 80 after $18 \mathrm{~h}$ of growth in TSB medium was estimated at $1,600 \mathrm{AU} / \mathrm{mL}$. Heating at 80,100 , or $121^{\circ} \mathrm{C}$ had no effect on the antibacterial activity. Inhibition zones produced following heat treatments were comparable to those of control samples kept at $4^{\circ} \mathrm{C}$, indicating that the putative bacteriocins produced were heat-resistant.

Plasmids were recovered from 52 isolates showing activity against Listeria or SA305. These strains had a varying number of resident plasmids (1 to 3 ), with sizes estimated at 4, 8, and $12 \mathrm{~kb}$ (Figure 1 ). The presence of an approximately 8-kb plasmid was a common feature in all isolates. The 3 strains selected for further studies (strains 48,76, and 80) each had only the 8-kb plasmid, which were correspondingly designated as p48, p76, and p80. A similar-size plasmid that carries the genes of the aureocin A70 (pRJ6) was described in staphylococcal strains isolated from bovine milk in Brazil by Giambiagi-Marval et al. (1990).

Several staphylococcal bacteriocin genes have been found in plasmids with lengths varying from 8 to $>50$ kb (Sahl and Brandis, 1981; Crupper and Iandolo, 1996; Crupper et al., 1997; Heidrich et al., 1998; Navaratna et al., 1998, 1999). The A70 and A53 aureocin plasmids originally described by Giambiagi-Marval et al. (1990) were reported to have antilisterial activity by Oliveira et al. (1998).

Table 1. Inhibition of Listeria monocytogenes Scott A (LMS), Listeria ivanovii (LIV), and Staphylococcus aureus Newbold 305 (SA305) by staphylococcal isolates from bovine milk

\begin{tabular}{lcrrr}
\hline Group & No. & & \\
& tested & LMS & LIV & SA305 \\
\hline Coagulase-positive staphylococci & 94 & 54 & 43 & 49 \\
Coagulase-negative staphylococci & 17 & 3 & 0 & 3 \\
Total & 111 & 57 & 43 & 52 \\
\hline
\end{tabular}




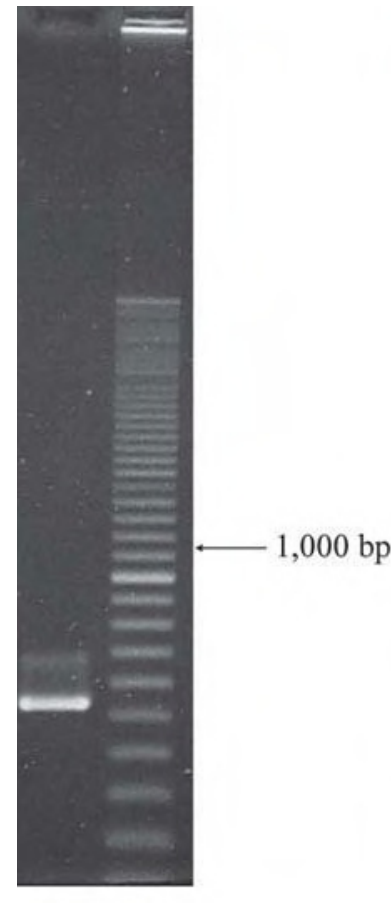

12

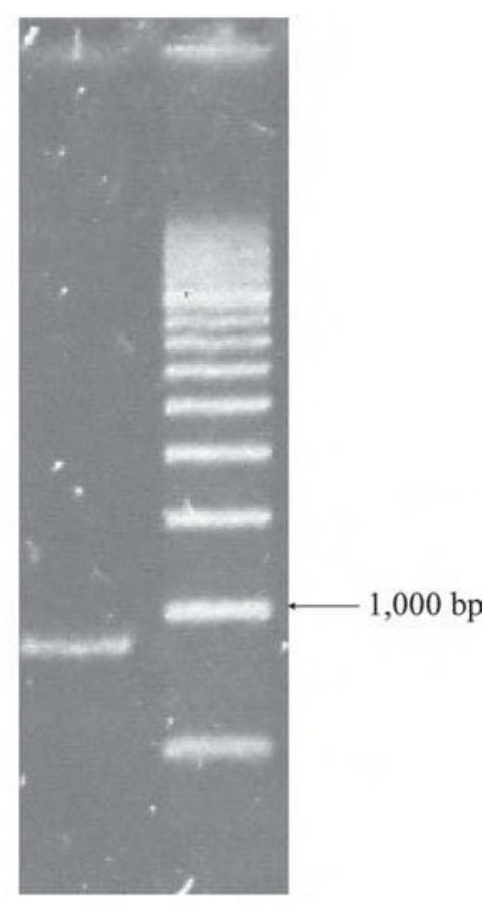

34
Figure 2. Products of PCR generated with primers flanking the aurc $A B C D$ operon (lane 1) and the replication gene (lane 3) in Staphylococcus aureus isolate 48; 100-bp (lane 2) and 500-bp (lane 4) molecular weight markers are shown.

Digestion with restriction enzymes showed that, similar to the published map of pRJ6 (Giambiagi-Marval et al., 1990), p76 and p80 had a single site for EcoRI and $P s t \mathrm{I}$ and 2 sites for EcoRV. The restriction fragments produced with EcoRV were similar in size $(\sim 2.5 \mathrm{~kb}$ and $5.5 \mathrm{~kb}$ ) to those described for pRJ6 (Giambiagi-Marval et al., 1990; Netz et al., 2001). Plasmid p48 also had a single site for EcoRI and PstI but had an extra site for EcoRV, resulting in fragments of approximately 2.1, 2.2 , and $3.7 \mathrm{~kb}$. The number of sites for HincII was also different in $\mathrm{p} 76$ and $\mathrm{p} 80$ and $\mathrm{p} 48$. The first 2 had 4 HincII sites, resulting in fragments of approximately $0.4,0.8,1.4$, and $5.4 \mathrm{~kb}$, whereas p48 had 5 sites and generated fragments of approximately $0.4,0.8,1.3,1.4$, and $4.1 \mathrm{~kb}$.

All 57 staphylococcal isolates showing antilisterial or anti-SA305 activity yielded a PCR product of approximately $525 \mathrm{bp}$ with primers specific for the A70 structural gene (Figure 2). The amplified product corresponded to the aur $A B C D$ aureocin operon of A70 (Netz et al., 2001) with either genomic DNA or isolated plasmid used as the template.

The PCR assays with DNA used as template from p48, p76, p80, and employing specific primers flanking the replication gene of pRJ6 were also conducted. The PCR product obtained was approximately $857 \mathrm{bp}$ with p48, p76, and p80, which is the expected size of the pRJ6 replicon (Figure 1). These results indicated that the 8 -kb plasmid found in the 3 staphylococcal strains may be similar or related to pRJ6, which was originally described to carry the genes of aureocin A70 (Giambiagi-Marval et al., 1990).

The uptake of $\mathrm{p} 48, \mathrm{p} 76$, and $\mathrm{p} 80$ by Staph. aureus SA113 (SA113; ATCC 35556) was accomplished by electroporation. After plating out the transformation mixtures, colonies were randomly picked and cultured overnight in TSB. Cell-free culture supernatants were checked for inhibition of LMS by the agar-well diffusion method. A total of 376,99 , and 75 colonies were checked against LMS after transformation of SA113 with $\mathrm{p} 48, \mathrm{p} 76$, and $\mathrm{p} 80$, respectively. The number of colonies showing inhibition zones after transformation with $\mathrm{p} 48, \mathrm{p} 76$, and $\mathrm{p} 80$ was 2,6 , and 5 , respectively. The presence of an approximately 8 -kb plasmid was confirmed in all isolates of transformed SA113. The digestion of purified plasmid preparations of p48, p76, and p80 from SA113 transformants with EcoRV and HincII yielded the expected pattern of restriction fragments. In addition, PCR products obtained with primers specific for the aureocin A70 structural gene and for the replicon of pRJ6 (the original plasmid of aureocin A70) were also identified.

According to the published map of pRJ6 (GiambiagiMarval et al., 1990) and genetic analyses of the 6,332-bp fragment of the plasmid (Netz et al., 2001), the 5.5-kb fragment obtained by EcoRV digestion would include the aureocin A70 structural and immunity genes and encode the transport system in addition to the replicon of the plasmid. Thus, the plasmid p 80 isolated from SA113 was digested with EcoRV and ligated to yield the smaller p80a $(\sim 5.5 \mathrm{~kb})$, which was transformed into SA113 and evaluated for activity against LMS. Plasmid analysis of 22 colonies with antilisterial activity confirmed the presence of the $5.5-\mathrm{kb}$ plasmid in 15 isolates, whereas 7 isolates harbored the apparently religated 8 -kb p80 plasmid. However, the inhibition zones produced by strains carrying the reduced-size plasmid were smaller than those produced by the bacteria carrying the p80 parent plasmid (data not shown). These results indicated that some functions related to the production or transport of the bacteriocin or plasmid replication may be located in the excised fragment.

Transformation of the commercial strain Staph. carnosus CS299 was attempted with purified p48 and p80 plasmids extracted from their original SA48 and SA80 strains or from the transformants SA113/p48 and SA113/p80. Staphylococcus carnosus was selected for the transformation experiments because it is a nonpathogenic, food-grade staphylococcus used in the fermentation of sausages (Schleifer and Fischer, 1982). As 
a starter culture, Staph. carnosus enhances the flavor and contributes to the reddening reaction in sausages (Hammes et al., 1995; Leroy et al., 2006); it has been used as a host for gene cloning and protein production (Gotz, 1990) in studies on bacteriocin gene expression (Schnell et al., 1992) and for surface display of heterologous gene products (Wernérus et al., 2002).

Several attempts were also made to transform Staph. carnosus CS299 with the plasmids isolated from strains 48 and 80. Although culture filtrates of Staph. carnosus isolates lacked antilisterial activity, transformants obtained with p48 contained an 8-kb plasmid in addition to the 4 -kb resident plasmid that in some isolates indicated loss of molecular mass possibly due to deletion mutation events (data not shown). Further, PCR analysis of the isolated 8-kb plasmid with primers to the aureocin A70 structural gene and the replicon of pRJ6 yielded amplification products with sizes of approximately 525 and $857 \mathrm{bp}$, which are the expected sizes of the aureocin A70 structural gene and the replicon of p48, respectively. This plasmid preparation from Staph. carnosus CS299 was also used successfully to transform SA113. The 40 colonies of SA113 transformants checked against LMS all produced inhibition zones. These results indicated that the bacteriocin plasmid p48 was transferred to Staph. carnosus CS299 but antilisterial activity was not expressed in this host. The failure of expression may be related to the lack of secretion of the bacteriocin by Staph. carnosus cells or to mechanisms that regulate the production of the bacteriocin. Although the expression of antibacterial activity of cloned lantibiotic genes in Staph. carnosus has been shown before (Schnell et al., 1992; Heidrich et al., 1998), attempts to transfer the whole bacteriocin plasmid of Staph. aureus C55 encoding a 2-component lantibiotic were unsuccessful (Navaratna et al., 1998).

The present investigation showed widespread production of bacteriocins by staphylococci isolated from bovine milk. Antimicrobial activity was mediated by an 8-kb plasmid, and the putative bacteriocin appeared to be identical to or a natural variant of aureocin A70. The production of aureocin A70 is plasmid mediated and was described by Giambiagi-Marval et al. (1990) in Staph. aureus isolated from milk samples in Brazil. Subsequently, it was reported in Staph. aureus isolated from Argentinian and Brazilian dairy herds (Nascimento et al., 2002, 2005a) and also in CNS recovered from cases of bovine subclinical mastitis (Nascimento et al., 2005b).

The bacteriocin plasmid was successfully transferred to SA113, a plasmid-free strain that is commonly used as recipient for electroporation of staphylococcus plasmids (Lee, 1995). The transformed bacteria expressed the inhibitory activity against LMS and produced in- hibition zones similar in size as the original cultures. The plasmid was also transferable by electroporation to Staph. carnosus, but inhibitory activity could not be demonstrated against LMS.

Genes that regulate the expression of lantibiotics (Siezen et al., 1996) may also be necessary for the expression of the aureocin A70. It was found that when p80 from SA113 transformants was digested with EcoRV and religated to the reduced size p80a (5.5 $\mathrm{kb})$, smaller inhibition zones were produced against $L$. monocytogenes than with the whole plasmid. The approximately $2.5-\mathrm{kb}$ excised fragment possibly encoded some of the functions related to bacteriocin production or secretion.

In addition to the antilisterial effect that may help in controlling outbreaks of milk-borne listeriosis, another noteworthy finding in this study was the anti-SA305 activity of aureocin-producing staphylococcal isolates that naturally occur in many milk samples collected from Brazilian dairy herds. Staphylococci are responsible for approximately $30 \%$ of bovine mastitis outbreaks (Sutra and Poutrel, 1994), and Staph. aureus SA305 is 1 of the 3 major serotypes of staphylococci that account for $100 \%$ of US and $98 \%$ of European cases of intramammary infections in cows (Guidry et al., 1998). Because the prevention of bovine mastitis by vaccine therapy has had limited success and strategies involving the production of recombinant lysostaphin by genetically enhanced cows are still in development (Wall et al., 2005), consideration should be given to further research on aureocin-producing nonpathogenic staphylococci to evaluate their potential as natural antimicrobial agents for controlling the growth of infectious staphylococci involved in the outbreaks of mastitis on dairy farms.

\section{REFERENCES}

Augustin, J., and F. Gotz. 1990. Transformation of Staphylococcus epidermidis and other staphylococcal species with plasmid DNA by electroporation. FEMS Microbiol. Lett. 54:203-207.

Barrow, G. I. 1963. The nature of inhibitory activity by Staphylococcus aureus Type 71. J. Gen. Microbiol. 32:255-261.

Chen, H., and D. G. Hoover. 2003. Bacteriocins and their food applications. Comp. Rev. Food Sci. Food Safety 2:82-100.

Cottrell, M. T., and D. L. Kirchman. 2000. Community of marine bacterioplankton determined by $16 \mathrm{~S}$ rRNA gene clone libraries and fluorescence in situ hybridization. Appl. Environ. Microbiol. 66:5116-5122.

Crupper, S. S., A. J. Gies, and J. J. Iandolo. 1997. Purification and characterization of staphylococcin BacR1, a broad-spectrum bacteriocin. Appl. Environ. Microbiol. 63:4185-4190.

Crupper, S. S., and J. J. Iandolo. 1996. Purification and partial characterization of a novel antibacterial agent (Bac1829) produced by Staphylococcus aureus KSI1829. Appl. Environ. Microbiol. 62:3171-3175.

Dajani, A. S., and L. W. Wannamaker. 1969. Demonstration of a bactericidal substance against $\beta$-hemolytic streptococci in supernatant fluids of staphylococcal cultures. J. Bacteriol. 97:985-991.

Deegan, L., P. D. Cotter, C. Hill, and P. Ross. 2006. Bacteriocins: Biological tools for bio-preservation and shelf-life extension. Int Dairy J. 16:1058-1071. 
Ekkelenkamp, M. B., M. Hanssen, S. D. Hsu, A. de Jong, D. Milatovic, J. Verhoef, and N. A. J. Van Nuland. 2005. Isolation and structural characterization of epilancin 15X, a novel lantibiotic from a clinical strain of Staphylococcus epidermidis. FEBS Lett. 579:1917-1922.

Gagliano, V. J., and R. D. Hinsdill. 1970. Characterization of a Staphylococcus aureus bacteriocin. J. Bacteriol. 104:117-125.

Giambiagi-Marval, M., M. A. Mafra, E. G. C. Penido, and M. C. F. Bastos. 1990. Distinct groups of plasmids correlated with bacteriocin production in Staphylococcus aureus. J. Gen. Microbiol. 136:1591-1599.

Gotz, F. 1990. Staphylococcus carnosus: A new host organism for gene cloning and protein production. Soc. Appl. Bacteriol. Symp. Ser. 19:49S-53S.

Guidry, A., A. Fattom, A. Patel, C. O'Brien, S. Shepard, and J. Lohuis. 1998. Serotyping scheme for Staphylococcus aureus isolated from cows with mastitis. Am. J. Vet. Res. 59:1537-1539.

Hammes, W.P., I. Bosch, and G. Wolf. 1995. Contribution of Staphylococcus carnosus and Staphylococcus piscifermentans to the fermentation of protein foods. J. Appl. Bacteriol. 79(Symp. Suppl.):76-83.

Heidrich, C., U. Pag, M. Josten, J. Metzger, R. W. Jack, G. Bierbaum, G. Jung, and H. G. Sahl. 1998. Isolation, characterization, and heterologous expression of the novel lantibiotic epicidin 280 and analysis of its biosynthetic gene cluster. Appl. Environ. Microbiol. 64:3140-3146.

Henderson, J. T., A. L. Chopko, and P. D. Wassenaar. 1992. Purification and primary structure of pediocin PA-1 produced by Pediococcus acidilactici. Arch. Biochem. Biophys. 295:5-12.

Jack, R. W., J. R. Tagg, and B. Ray. 1995. Bacteriocins of grampositive bacteria. Microbiol. Rev. 59:171-200.

Lee, J. C. 1995. Electroporation of staphylococci. Methods Mol. Biol. 47:209-216.

Leroy, F., J. Verluyten, and L. De Vuyst. 2006. Functional meat starter cultures for improved sausage fermentation. Int. J. Food Microbiol. 106:270-285.

Minamikawa, M., Y. Kawai, N. Inoue, and K. Yamazaki. 2005. Purification and characterization of warnericin RB4, anti-Alicyclobacillus bacteriocin, produced by Staphylococcus warneri RB4. Curr. Microbiol. 51:22-26.

Nascimento, J. S., P. C. Fagundes, M. A. V. P. Brito, K. R. N. Santos, and M. C. F. Bastos. 2005a. Production of bacteriocins by coagulase-negative staphylococci involved in bovine mastitis. Vet. Microbiol. 106:61-71.

Nascimento, J. S., M. Giambiagi-Marval, S. S. Oliveira, H. Ceotto, K. R. N. Santos, and M. C. F. Bastos. 2005b. Genomic fingerprinting of bacteriocin-producer strains of Staphylococcus aureus. Res. Microbiol. 156:837-842.

Nascimento, J. S., K. R. N. Santos, E. Gentilini, D. Sordelli, and M. C. F. Bastos. 2002. Phenotypic and genetic characterisation of bacteriocin-producing strains of Staphylococcus aureus involved in bovine mastitis. Vet. Microbiol. 85:133-144.

Navaratna, M. A. D. B., H. G. Sahl, and J. R. Tagg. 1998. Twocomponent anti-Staphylococcus aureus lantibiotic activity produced by Staphylococcus aureus C55. Appl. Environ. Microbiol. 64:4803-4808.

Navaratna, M. A. D. B., H. G. Sahl, and J. R. Tagg. 1999. Identification of genes encoding two-component lantibiotic production in Staphylococcus aureus $\mathrm{C} 55$ and other phage group II S. aureus strains and demonstration of an association with exfoliative toxin B gene. Infect. Immun. 67:4268-4271.

Netz, D. J. A., R. Pohl, A. G. Beck-Sickinger, T. Selmer, A. J. Pierik, M. C. F. Bastos, and H. G. Sahl. 2002. Biochemical characterisation and genetic analysis of aureocin A53, a new atypical bacteriocin from Staphylococcus aureus. J. Mol. Biol. 319:745-756.

Netz, D. J. A., H. G. Sahl, R. Marcelino, R. J. S. Nascimento, S. S Oliveira, M. B. Soares, and M. C. F. Bastos. 2001. Molecular characterisation of aureocin A70, a multipeptide bacteriocin isolated from Staphylococcus aureus. J. Mol. Biol. 311:939-949.

O'Sullivan, D., and T. R. Klaenhammer. 1993. Rapid mini-prep isolation of high-quality plasmid DNA from Lactococcus and Lactobacillus spp. Appl. Environ. Microbiol. 59:2730-2733.
O'Sullivan, L., R. P. Ross, and C. Hill. 2002. Potential of bacteriocinproducing lactic acid bacteria for improvements in food safety and quality. Biochimie 84:593-604.

Oliveira, S. S., J. S. Nascimento, D. C. Povoa, S. A. Araujo, M. R. Gamon, and A. C. F. Bastos. 1998. Genetic analysis of the bacteriocin-encoding plasmids pRJ6 and pRJ9 of Staphylococcus aureus by transposon mutagenesis and cloning of genes involved in bacteriocin production. J. Appl. Microbiol. 85:972-984.

Papagianni, M. 2003. Ribosomally synthesized peptides with antimicrobial properties: Biosynthesis, structure, function, and applications. Biotechnol. Adv. 21:465-499.

Rogolsky, M., and B. B. Wiley. 1977. Production and properties of a staphylococcin genetically controlled by staphylococcal plasmid for exfoliative toxin synthesis. Infect. Immun. 15:726-732.

Sahl, H. G., and G. Bierbaum. 1998. Lantibiotics: Biosynthesis and biological activities of uniquely modified peptides from gram-positive bacteria. Annu. Rev. Microbiol. 52:41-79.

Sahl, H. G., and H. Brandis. 1981. Production, purification and chemical properties of an antistaphylococcal agent produced by Staphylococcus epidermidis. J. Gen. Microbiol. 127:377-384.

Sashihara, T., H. Kimura, T. Higuchi, A. Adachi, H. Matsusaki, K. Sonomoto, and A. A. Ishizaki. 2000. A novel lantibiotic nukacin ISK-1 of Staphylococcus warneri ISK-1: Cloning of the structural gene and identification of the structure. Biosci. Biotechnol. Biochem. 64:2420-2428.

Schenk, S., and R. A. Laddaga. 1992. Improved method for electroporation of Staphylococcus aureus. FEMS Microbiol. Lett. 73:133138.

Schleifer, K., and K. H. Fischer. 1982. Description of a new species of the genus Staphylococcus: Staphylococcus carnosus. Int. J. Syst. Bacteriol. 32:153-156.

Schnell, N., G. Engelke, J. Augustin, R. Rosenstein, V. Ungerman, F. Gotz, and K. D. Entian. 1992. Analysis of genes involved in the biosynthesis of lantibiotic epidermin. Eur. J. Biochem. 204:5768.

Schnell, N., K. D. Entian, F. Götz, T. Horner, R. Kellner, and G. Jung. 1989. Structural gene isolation and prepeptide sequence of gallidermin, a new lanthionine containing antibiotic. FEMS Microbiol. Lett. 49:263-267.

Siezen, R. J., O. P. Kuipers, and W. M. de Vos. 1996. Comparison of lantibiotic gene clusters and encoded proteins. Antonie van Leeuwenhoek 69:174-184.

Somkuti, G. A., and D. H. Steinberg. 1988. Genetic transformation of Streptococcus thermophilus by electroporation. Biochimie 70:579585.

Stougaard, P., and S. Molin. 1983. Vertical dye-buoyant density gradients for rapid analysis and preparation of plasmid DNA. Anal. Biochem. 118:191-193.

Sutra, L., and B. Poutrel. 1994. Virulence factors involved in the pathogenesis of bovine intramammary infections due to Staphylococcus aureus. J. Med. Microbiol. 40:79-89.

Tagg, J. R., and A. R. McGiven. 1971. Assay system for bacteriocins. Appl. Microbiol. 21:943.

van de Kamp. M., L. M. Horstink, H. W. Van den Hooven, R. N. H. Konings, C. W. Hilbers, A. Frey, H. G. Sahl, J. W. Metzger, and F. J. M. Van de Ven. 1995. Sequence analysis by NMR spectroscopy of the peptide lantibiotic epilancin K7 from Staphylococcus epidermidis K7. Eur. J. Biochem. 227:757-771.

Wall, R. J., A. M. Powell, M. J. Paape, D. E. Kerr, D. D. Bannerman, V. G. Pursel, K. D. Wells, N. Talbot, and H. W. Hawk. 2005. Genetically enhanced cows resist intramammary Staphylococcus aureus infection. Nat. Biotechnol. 23:445-451.

Warren, R., M. Rogolsky, B. B. Wiley, and L. A. Glasgow. 1975. Isolation of extrachromosomal deoxyribonucleic acid for exfoliative toxin production from phage group II Staphylococcus aureus. J. Bacteriol. 122:99-105.

Wernérus, H., J. Lehtiö, P. Samuelson, and S. Stahl. 2002. Engineering of staphylococcal surfaces for biotechnological applications. J. Biotechnol. 96:67-78. 